\title{
Soil microbial carbon pump: Mechanism and appraisal
}

\author{
Chao Liang* \\ Institute of Applied Ecology, Chinese Academy of Sciences, Shenyang 110016, China
}

ARTICLE INFO

Article history:

Received May 13, 2020

Revised July 7, 2020

Accepted July 13, 2020

Keywords:

Microbial carbon pump

Microbial necromass

Biomarker

Soil carbon stabilization

Soil organic matter

Global change

\begin{abstract}
A B S T R A C T
The soil microbial carbon pump (MCP) conceptualizes a sequestration mechanism based on the process of microbial production of a set of new organic compounds, which carry the carbon from plant, through microbial anabolism, and enter into soil where it can be stabilized by the entombing effect. Understanding soil MCP and its related entombing effect is essential to the stewardship of ecosystem services, provided by microbial necromass in the formation and stabilization of soil organic matter as well as its resilience and vulnerability to global change. The mechanism and appraisal of soil MCP, however, remain to be elucidated. This lack of knowledge hampers the improvement of climate models and the development of land use policies. Here, I overview available knowledge to provide insights on the nature of the soil MCP in the context of two main aspects, i.e., internal features and external constraints that mechanistically influence the soil MCP operation and ultimately influence microbial necromass dynamics. The approach of biomarker amino sugars for investigation of microbial necromass and the methodological limitations are discussed. Finally, I am eager to call new investigations to obtain empirical data in soil microbial necromass research area, which urgently awaits synthesized quantitative and modeling studies to relate to soil carbon cycling and climate change.
\end{abstract}

(C) Higher Education Press 2020

\section{Introduction}

The carbon (C) cycle plays a key role in regulating Earth's global temperature by influencing the amount of greenhouse gases, such as $\mathrm{CO}_{2}$, in the atmosphere. Whether or not terrestrial ecosystem can serve as net $C$ sink to mitigate climate change in the coming decades is a matter of great interest. Terrestrial ecosystems have the potential to store $\mathrm{C}$, as $\mathrm{CO}_{2}$ is fixed in plants as biomass (representing a shortterm C storage pool) via the process of photosynthesis, and further converts a portion of those plant biomass into the soil organic C (SOC) pool by microbial metabolic activities that lead to a long-term C storage (Schimel and Schaeffer, 2012;

\footnotetext{
* Corresponding author

E-mail address: cliang823@gmail.com (C. Liang)
}

Liang et al., 2017). The SOC pool, as twice the size of the atmospheric $C$ pool, is the largest dynamic terrestrial $C$ pool, so even small changes in it are so large that they could have a significant impact on atmospheric $\mathrm{CO}_{2}$ level (Eswaran et al., 1993; Stockmann et al., 2013). Microorganisms have now been considered important as both the primary agents of SOC decomposition and the dominant agents of SOC formation, understanding $C$ dynamics in soils therefore stems from the understanding of microbial-mediated processes related to SOC dynamics (Bradford et al., 2016; Liang et al., 2017). Such processes are important to be explored to understand their role in controlling atmospheric $\mathrm{CO}_{2}$ level and land productivity.

Soil $\mathrm{C}$ transformation and sequestration have been hotly discussed in recent years due to our evolving knowledge over time on soil organic matter (SOM) formation (Schmidt et al., 2011; Cotrufo et al., 2013; Lehmann and Kleber, 2015; Liang et al., 2017; Sokol et al., 2019; Anthony et al., 2020). 
Traditionally, long-lasting soil $\mathrm{C}$ was considered to be formed by chemical condensation into large, complex, and chemically recalcitrant "humic materials" (Stevenson, 1994); this view has been largely discredited at current years because SOM is increasingly seen as being comprised of small molecules that are the result of microbial metabolisms, including microbial biomass and microbial processed compounds (Miltner et al., 2012; Lehmann and Kleber, 2015). Further, mounting evidence has continuously suggested that the incorporation of microbial biomass components into soils via microbial remnants is likely to be disproportionately large (Miltner et al., 2012; Fan and Liang, 2015; Kallenbach et al., 2016; Craig et al., 2018). As shown in the Fig. 1, microbial necromass inputs can play a far greater role in the sequestration of $C$ into soils than traditionally believed, particularly when a significant portion of those inputs are more likely to be stabilized rather than plant inputs (Liang et al., 2017; Ma et al., 2018). Fundamentally, microbial necromass formation is an outcome of microbial anabolism, which can actively influence the processes of soil $\mathrm{C}$ formation and transformation. However, it remains largely elusive regarding the microbial anabolic controls on SOM processes and their interactions with biotic and abiotic factors. Here, I narrow down the role of microbial anabolism in the creation of SOM using the recently-proposed concept of soil microbial carbon pump (MCP) (Liang et al., 2017). I discuss the mechanism and appraisal of soil MCP as

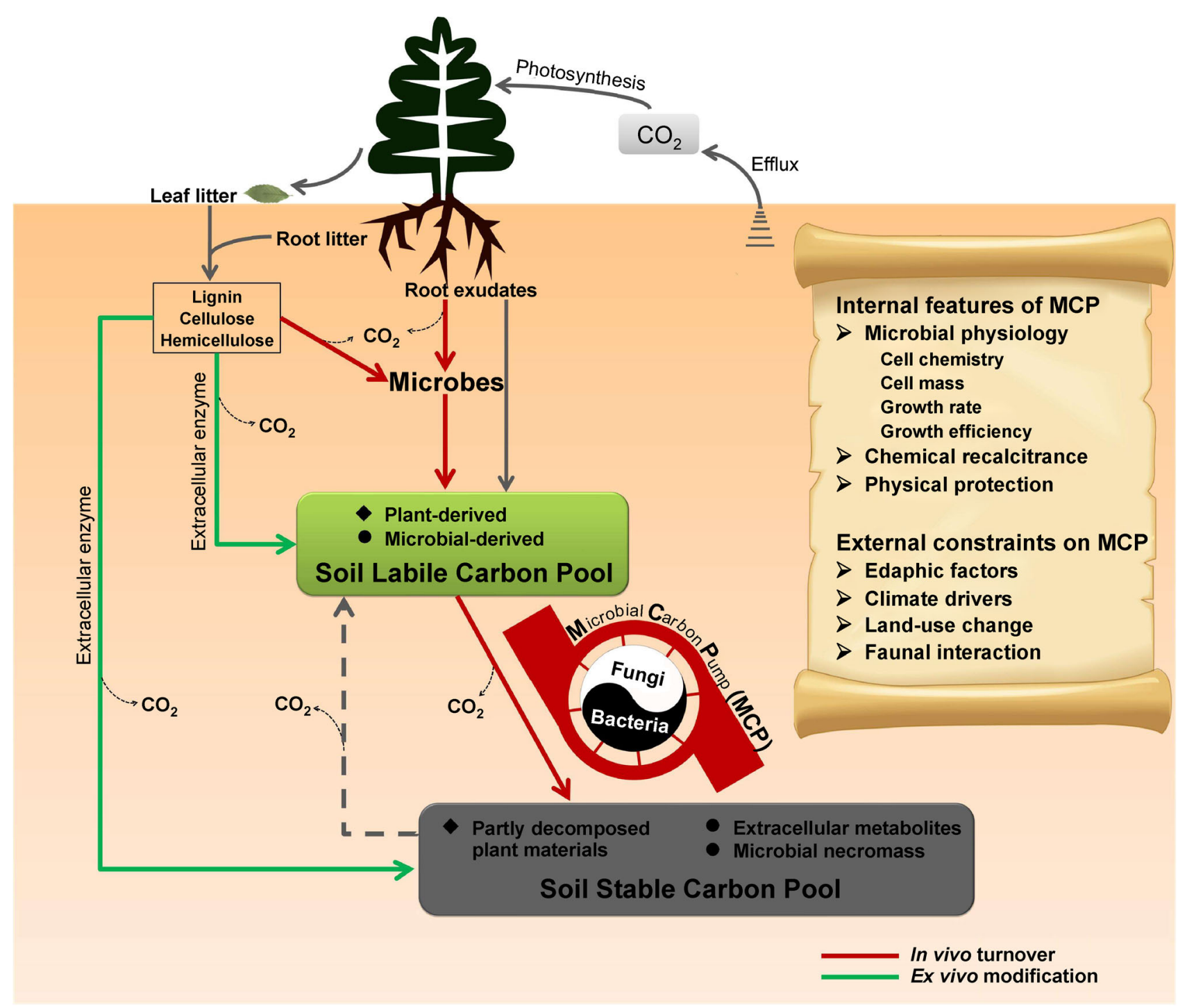

Fig. 1 Diagram showing the soil microbial carbon pump (MCP) and the potential factors in the context of internal features and external constraints (modified from Liang et al., 2017 Nature Microbiology, 2: 17105). The soil MCP is a conceptual object to demonstrate the fact that microbial necromass and metabolites can be the precursors for persistent soil organic matter, which particularly highlights the importance of microbial anabolism in soil carbon storage. The yin-yang symbol in the MCP image is used to illustrate the carbon conversion to microbial necromass is driven, but driven differently, by both bacteria and fungi with different trophic strategies. Specificity to only plant deposits is set in the diagram, although the soil MCP concept can apply to multiple types of organic substrate including anthropogenic and animal inputs. 
well as its resilience to disturbance or changing environmental conditions.

\section{Soil microbial carbon pump (MCP)}

The MCP posits a mechanistic concept of $C$ sequestration via microbial anabolism, first raised by marine scholars (Jiao et al., 2010), and is shaping a new direction in ocean C cycle research (Lechtenfeld et al., 2015; Jiao et al., 2018). Simply, the MCP describes that microbes can play a dominant role in "pumping" bio-available $\mathrm{C}$ into a pool of persistent organic compounds after passing through their biomass in environments. In terrestrial system, the soil MCP moves microbially synthesized compounds into soil where it can be stabilized by intimate physical interaction on soil minerals or within aggregates, as called the entombing effect (Liang et al., 2017). Compared to relatively much research on the MCP in oceans, somewhat less effort has focused on the soil MCP, which nevertheless can and actually is revolutionizing our view of soil $\mathrm{C}$ sequestration and further global $\mathrm{C}$ cycling.

The soil MCP provides a formalized focus on the flow and microbial transformation of plant-derived $C$ through microbial biomass and ultimately conversion into the stable soil $\mathrm{C}$ pool (Liang and Balser, 2011; Liang et al., 2017). Microbes residing in soil can grow and turn over rapidly during decomposition of plant litters and other soil organic materials for building microbial biomass (Liang et al., 2011; Miltner et al., 2012). Then, after cell death several organic cell compounds release into soils via microbial necromass, including cell envelope fragments and colloidal former cytosolic matter that survived re-utilization by the next microbial generation (Liang et al., 2019); part of those necromass can be stabilized in soils for extended periods whether via protection by physical interactions or lack of activation energy due to chemical composition (Liang et al., 2017). In soil science field, the microbial-driven conversion of organic materials into stable soil $\mathrm{C}$ pool (here, soil MCP) has been conceptually considered since a long time ago (Kögel-Knabner, 2002), but until relatively recent years it started gaining increasing attentions as a primary pathway of SOM formation due to mounting empirical evidence to support its predominant importance in later years (Simpson et al., 2007; Kallenbach et al., 2016; Tao et al., 2017; Shao et al., 2019; Sokol and Bradford, 2019).

Direct microbial contributions to sequestered $C$ have historically been regarded as low and even ignored as negligible in many instances, as active living microbial biomass makes up $<5 \%$ of soil organic matter (SOM) (Wardle, 1992; Dalal, 1998; Xu et al., 2013), and total microbial biomass $\mathrm{C}$ was reported $<4 \%$ of the SOC (Anderson and Joergensen, 1997). However, the belief of insignificant microbial contribution to SOC pool might not be a valid perception as living biomass alone does not properly indicate long-term C dynamics (Potthoff et al., 2008; Liang et al., 2011). Indeed, empirical data and conceptual models all suggest that microbial contributions to SOC could be disproportionately large relative to the living biomass. Microbial necromass can exist as relatively recalcitrant polymers, some of which have been suggested as important components of stable $C$ pool in soils (Guggenberger et al., 1999; Liang and Balser, 2008; Ludwig et al., 2015). Qualitatively, ${ }^{13} \mathrm{C}-\mathrm{NMR}$ analysis showed that microbial metabolic products have similar structures to stable humic substances, which indicates a significant incorporation of microbial-derived C (Simpson et al., 2007). In addition, microbial-derived moieties are found stabilized into finer soil particles over time based on analysis of biomarkers, e.g., higher ratios of hexose to pentose and greater amino sugar contents were detected in finer relative to coarser soil fractions, indicating the high contribution of microbial necromass to more stable soil C pools (Guggenberger et al., 1994; Kiem and Kogel-Knabner, 2003). For quantitative aspect, Liang et al. (2011) modeled and simulated the turnover of microbial biomass using an Absorbing Markov Chain, in which the relative amounts of microbial living biomass and dead necromass in soils were calculated, suggesting that microbial necromass $C$ could be about 40 times greater than living biomass $\mathrm{C}$. If we assume microbial living biomass $\mathrm{C}$ is $2 \%$ of the total SOC, the $\mathrm{C}$ in the necromass would account for $80 \%$ of the organic $C$ in soils (Liang and Balser, 2011). Recently, Liang et al. (2019) estimated the contribution of microbial necromass to the topsoil organic $\mathrm{C}$ in temperate agricultural, grassland, and forest ecotypes, averagely ranging from $30 \%$ to $60 \%$. From another view, Whitman et al. (1998) calculated the total amount of prokaryotic cellular $C$ in the world (350-550 pg of $\mathrm{C})$, and suggested that prior estimates of this value were likely too conservative. If we account for fast microbial turnover and the ubiquity of fungi that present in soil, the amount of microbial-derived $\mathrm{C}$ in terrestrial systems is likely enormous. In sum, microbial necromass can result in a significant net contribution of microbial-derived $\mathrm{C}$ to the stable soil $\mathrm{C}$ pool.

As the stable SOC pool is the most important for long-term C sequestration (Swift, 2001), research on the soil MCP, particularly how it governs soil $\mathrm{C}$ cycling and how it may respond to global change, is critical for understanding microbial involvement and control over SOC stabilization and consequently for global $\mathrm{C}$ cycling. A conceptual framework associated with the soil MCP model has been recently established to demonstrate the relevant pathways and effects of soil MCP (Liang et al., 2017). Accordingly, the main consequence of the soil MCP refers to the formation and accumulation of microbial necromass in soils, and the underlying mechanism of the soil MCP will determine a soil's capacity to retain persistent organic C. However, insufficient knowledge about the mechanism and appraisal of soil MCP is yet to be fully understood.

\section{Mechanistic understanding of soil MCP}

Understanding whether and, if so, how microbial necromass dynamics get changed will enhance our knowledge of how the soil MCP operates and serves ecosystem functions. I integrate available knowledge to provide insights on the 
nature of the soil MCP in the context of two main aspects: the internal features of the MCP and the external constraints that regulate the MCP.

\subsection{Internal features of MCP}

\subsubsection{Microbial physiology}

Microbial physiological traits, such as cell chemistry, cell mass, growth rate, and growth efficiency, can influence microbial necromass production, accumulation, and persistence in soils. Those traits can differ in different microbial species or taxa, and may directly impact on the quantity and composition of microbial biomass generated during microbial growth and activity. Part of that biomass will contribute to SOC storage as a series of derivative forms of necromass along with degradation. Specifically, microbial growth rate and growth efficiency, defined as number of cells generated per unit of time and amount of biomass generated per unit of substrate utilization, have been widely used as indices in a large volume of literature, which has suggested that there is a large variability in microbial handling of individual substrates (Lee and Schmidt, 2014; Geyer et al., 2016) and might be predicted by the number of rRNA genes in microbial genomes (Roller et al., 2016). Despite recent evidence showing that higher microbial growth rate and efficiency can increase $\mathrm{C}$ storage in agricultural soils (Kallenbach et al., 2015) and in grassland soils (Poeplau et al., 2019), there still remains great uncertainty regarding how and in which directions these traits will impact SOC pools (Anthony et al., 2020; Malik et al., 2020). For example, higher microbial growth efficiency can augment SOC storage by increasing the amount of $\mathrm{C}$ from soil microbial biomass and ultimately necromass, while increased microbial biomass $\mathrm{C}$ may also enhance production of Cdegrading enzymes leading to decreased soil C stocks (Kivlin et al., 2013). The impacts of microbial physiological traits on SOC dynamics can also vary at multiple ecological scales (Geyer et al., 2016). At the individual level, those microbial physiologic traits can differ along with growth stages and among niche environments associated with different stressors, where each individual microbial species has their own optimal growth rate and growth efficiency; at the community level, those traits each represent an averaged feature, as influenced by the relative abundance of different species or functional groups and by their responses to environmental disturbances. We may believe that the microorganisms themselves, as executor of the soil MCP for biomass production and necromass accumulation, act as a critical steward for $\mathrm{C}$ storage in terrestrial ecosystems.

\subsubsection{Chemical recalcitrance}

Molecular properties of a chemical compound, including molecule size, polarity, ether-bridges, and chemical bond type, determine its relative stability. In general, simple monomers with low molecular weight are labile and easily utilized by organisms, while high molecular weight polymers have relatively longer retention time (Malik et al., 2016). Hence, the chemical complexity of a microbial cell and its degradation products can influence to what extent those Ccontaining compounds will persist in soils. Aliphatic components are often abundant in SOM (Kögel-Knabner, 2002) and presumed to result from incorporation of microbial-derived products (microbial recycled) and microbial-altered plant structures (exocellular modification), but how the microbial anabolism-induced $\mathrm{C}$ contributes quantitatively to preservation of soil aliphatic compounds remains unclear. In other words, there is little information on what proportion of microbial-derived compounds, driven by the soil MCP, is persistent in the soil $\mathrm{C}$ pool. Prior studies have reported that most of the nitrogen in SOM (based on ${ }^{15} \mathrm{~N}-\mathrm{NMR}$ ) is in the form of amides, apparently derived from senesced microbial biomass (Knicker, 2000), and that some microbial synthesized compounds can be extremely difficult to decompose (Rillig et al., 2001; Knicker, 2004). By using amino sugar analysis, Guggenberger et al. (1999) found that SOM contained two to three orders of magnitude more of those microbial-derived compounds than were bound in living microbial biomass. Indeed, most microbial cell components are macromolecule polymers that may resist degradation to some extent (Amelung, 2001). Despite the (bio)chemical stability of complex microbial-derived polymeric structures, there is substantial evidence suggesting that the persistence of unaltered organic compounds (whether microbial or plant origin) in soil has little to do with molecular structural characteristics, but rather, is mostly due to other, nonchemical stabilization mechanisms (Lehmann and Kleber, 2015).

\subsubsection{Physical protection}

Physical protection as a stabilization mechanism for $\mathrm{C}$ storage in soils has drawn increasing attention in recent years as studies have shown that interactions between SOC and minerals play a more important role in $C$ sequestration than the chemical structure of organic molecules (Mikutta et al., 2006; Schmidt et al., 2011; Dungait et al., 2012). Physical protection of SOC includes spatial inaccessibility due to entrapment within soil aggregates and pore space as well as stabilization due to sorption to soil minerals (Sollins et al., 1996; Baldock and Skjemstad, 2000; von Lützow et al., 2006; Jastrow et al., 2007; Kögel-Knabner et al., 2008; Lehmann and Kleber, 2015). Most studies investigating the impact of mineral interactions with SOC had focused on humic acids (Schlautman and Morgan, 1994) or simple humic acid surrogates (Kubicki et al., 1999), in which soil microbial necromass usually was not clearly defined. Recent efforts have been made to focus on the formation and persistence of microbial necromass in relation to mineralogy, but associated mechanisms have just started to be understood (Pronk et al., 2015; Creamer et al., 2019). Nevertheless, isotopic analyses have demonstrated ${ }^{14} \mathrm{C}$ enrichment of microbial sugars in mineral-bound organic matter fractions, suggesting that microbial-derived polysaccharides are most likely stabilized 
preferentially by mineral interactions compared to plantderived polysaccharides (Rumpel et al., 2010). One direct study on degradation of ${ }^{13} \mathrm{C}$-labeled extracellular DNA showed that kaolinite amendment can decrease DNA decomposition rates significantly, and amended soils retain a much higher fraction of DNA-C than unamended soils, indicating that clay minerals may stabilize DNA-derived $C$ (Morrissey et al., 2015). Based on the mass balance of a soil microcosm with ${ }^{13} \mathrm{C}$-labeled bacterial cells and on the visualization of microbial residues by means of scanning electron microscopy, Miltner et al. (2012) posited that microbial cell compounds interact with soil minerals and become stabilized through forming patchy fragments, a process they termed the "patchy fragment formation cycle." This mineral-interaction process is consistent with the "Microbial Efficiency-Matrix Stabilization" conceptual model (Cotrufo et al., 2013) and "entombing effect" concept (Liang et al., 2017), which can well explain the efficient stabilization of easily-degradable microbial cell compounds found in soils, such as polysaccharides (Kiem and Kogel-Knabner, 2003), carbohydrates and fatty acids (Ludwig et al., 2015), and biomass-derived compounds in general (Simpson et al., 2007). Such interactions are also consistent with the concept of protection of labile substrates via the inaccessibility created by the filling of soil pores at the submicron scale, which could be related to the idea of physical occlusion of organic coatings on clay minerals through the formation of clay-sized aggregates and nano-scale structures (Lehmann et al., 2007; McCarthy et al., 2008; Monreal et al., 2010).

\subsection{External constraints on MCP}

Microbial necromass dynamics in soils involve two simultaneous and fundamental sets of processes: 1) the production of microbial biomass and necromass, and 2) the concomitant mineralization of those microbial synthesized products. These two processes are influenced by abiotic factors such as climate and soil properties, and also by biotic factors such as organisms and human activities. It is a challenging task to tease apart these two processes, i.e., production and mineralization, when studying microbial necromass dynamics, and even more challenging to separately evaluate each individual process, as affected by external influential variables. As a result, investigations of soil microbial necromass dynamics have often focused on the net effects of the soil MCP function.

\subsubsection{Edaphic factors}

The stabilization of microbial necromass in soils should be linked to soil properties (Amelung, 2001). So far, only a few sporadic studies have explored those linkages beyond SOC. The size of SOC pool has been often related to a soil's innate capacity to retain microbial necromass as evaluated by biomarker amino sugars (Zhang et al., 1999; Liang et al., 2007; Martins et al., 2012). Additional studies also found a similar strong correlation between SOC and total amino sugars across the broad range of climatic conditions of the North American prairie (Amelung et al., 2001), along a mountain altitudinal gradient (Zhang et al., 2013) and a temperate forest successional stage (Shao et al., 2019). We are lacking knowledge of knowing how other soil properties, e.g., $\mathrm{pH}$ and stoichiometry, influence soil microbial necromass dynamics, despite that many of which can significantly affect microbial community structure and activity. The magnitude of the soil microbial necromass pool appears to be determined by historical edaphic attributes related to soil development, such as clay contents (Liang et al., 2013; Khan et al., 2016; Ma et al., 2018), than by what type of organisms are present.

Based on a prior study that focused on how microbial biomass lipids and general soil attributes affected microbial amino sugars under biofuel cropping systems (Liang et al., 2013), soil properties such as total $C$ and clay content, but not existing biota (biofuel crop species and microbial functional group biomass), predicted soil amino sugar profiles, which suggests differences in microbial necromass among study sites were likely more due to differences in soil legacy properties rather than to current biotic drivers. The absence of any correlation between the current microbial composition (lipids) and legacies of past microbial activity (amino sugars) suggests that microbial necromass may represent ecosystem trends more faithfully when not being evaluated as static system properties. Thus, the size of the soil microbial necromass pool likely is significantly affected by the legacy conditions under which the MCP has been operating. This is also supported by the close linkage between necromass biomarker amino sugar concentrations and parent materials that experienced long and intense weathering in forest soils (Moritz et al., 2009; Ding et al., 2017).

\subsubsection{Climate drivers}

General concerns about climate change have led to growing interest in the response of terrestrial ecosystems to multiple environmental changes. Environmental change has been predicted to have major consequences for $\mathrm{C}$ cycling and soil ecosystem function. To date, the majority of studies investigating ecosystem $\mathrm{C}$ storage responses triggered by climate change drivers have focused on above-ground plant tissue chemistry and biomass production (Mooney et al., 1999), the dynamics of total soil C stock (Jastrow et al., 2005; van Groenigen et al., 2006), and microbial eco-physiological indices (Frey et al., 2008). However, somewhat limited studies have examined the persistence of soil microbial necromass as affected by climate change drivers (Glaser et al., 2006; Liang et al., 2015; Jia et al., 2017). Nevertheless, accurate prediction of the impact of climate change on microbial stabilization of SOC will require knowledge of the response of microbial-derived $\mathrm{C}$ to a range of environmental factors, from which we can further build an understanding of the intrinsic mechanisms underlying the persistence and transformation of microbial necromass $C$ in soil.

Simulated global change events (e.g., warming, elevated $\mathrm{CO}_{2}, \mathrm{~N}$ deposition) provide evidence that environmental 
change may impact the accumulation of microbial necromass storage in some soil systems (Glaser et al., 2006; van Groenigen et al., 2007; Liang et al., 2015; Jia et al., 2017; Ding et al., 2019). For example, in a California grassland ecosystem after continuous 9-year manipulation of climate change drivers, warming and $\mathrm{N}$ deposition were found to both deplete the fraction of $\mathrm{C}$ derived from microbes in soils, although two very different reasons explained the lowered proportion of microbial necromass in the total SOC pool. Under warming, microbial necromass decreased significantly while total SOC remained relatively constant, whereas under $\mathrm{N}$ deposition total SOC increased but microbial necromass decreased slightly (Liang and Balser, 2012). Microbial necromass decreases in response to warming and $\mathrm{N}$ deposition; a decrease in microbial contributions to the soil $C$ pool indicates a malfunction of the soil MCP, and the potential consequences could be severe. If persistent SOC accumulates and forms over the long-term (centuries to millennia), yet can be lost relatively quickly in response to perturbations, it will be difficult if not impossible to recover or restore this $C$ on decadal timescales. This type of impact on soil $C$ cycling might substantially disrupt the $C$ source-sink balance of terrestrial systems experiencing environmental climate change.

\subsubsection{Land-use change}

Anthropogenic land-use change is occurring worldwide across different ecosystems, driven by the demand to provide food, energy, and other resources for human consumption (Foley et al., 2005). Land-use changes, whether conversion from natural to managed or a switch in management practices on managed lands, transform the land surface, and consequently affect ecosystem functions, such as sustaining plant production, maintaining ecosystem health, and regulating climate.

Empirical studies have shown that anthropogenic land-use change, primarily agricultural management, can have substantial impacts on SOM and microbial necromass in soils (Joergensen et al., 2010; Ding et al., 2013; Zhang et al., 2014; Zhu et al., 2018; Zhu et al., 2020). For instance, long-term continuous cultivation was found to reduce biomarker amino sugars derived from microbial necromass (Zhang et al., 1999; Solomon et al., 2001), and other studies have observed a slow recovery of these markers over a decadal time scale when restoring degraded land (Amelung et al., 2001; Lauer et al., 2011). Specifically, the long-term effects of manure application on the amount and distribution of amino sugars within different aggregate size classes were assessed for an agricultural Mollisol (Ding et al., 2015); the study showed the aggregatespecific dynamics of microbial necromass and the rate of increase in amino sugars decreased with increasing manure application and ultimately reached an apparent saturation point. These observations on the dynamics of microbial necromass within aggregates suggest the soil MCP operates in a hierarchical manner and that the performance capacity of the MCP could be improved through alterations in anthropogenic land management practices.

\subsubsection{Faunal interaction}

Microbe-mediated $\mathrm{C}$ processes rarely occur in nature without the involvement of other organisms. Co-inhabiting with microorganism are numerous soil animals including herbivores, detritivores, microbivores, predators and omnivores (Bardgett and van der Putten, 2014). Despite increasing evidence demonstrating that soil fauna play a key role in decomposition, few studies have evaluated the contribution of soil fauna to microbial-derived $\mathrm{C}$ and its subsequent stabilization in soils (Crowther et al., 2015; Soong et al., 2016; Gan et al., 2018). However, it is safe to believe soil fauna manipulate soil MCP, significantly influencing SOM dynamics and microbial necromass production (Grandy et al., 2016). This is a rewarding area for future research to investigate the magnitude and direction of faunal effects on the function of the soil MCP.

We can identify three main avenues: 1) regulation of the quantity and quality of organic $\mathrm{C}$ entering the soil MCP; 2) topdown regulation of microbial population dynamics with subsequent controls on the size and efficiency of the soil MCP; 3) modification of soil structure as a result of the physical movement and activities of soil animals (Fig. 2).

1) Fauna may modify resource availability to microbes: in addition to frequently-discussed animal impacts on aboveground plant biomass and community, invertebrates that rely on living (roots or root products by herbivores) or dead (detritus by detritivores) plant materials for food may directly modify input rates of high-energy $C$ substrates available to microorganisms. By introducing feces or invertebrate cadavers, these phytophagous or saprotrophic animals can provide an alternate food resource for microorganisms (Hunter, 2001). As such, food resource availability and subsequent production of microbial biomass may increase under moderate phytophagy or detritivory by soil animals. Alternatively, outbreaks of root feeding pests or invasions by large populations of detritivores (such as invasive earthworms) could increase competition for $C$ resources with microbes, and subsequent diversion of organic $C$ into animal biomass may reduce the amount of $C$ entering the soil MCP and thus cause a decline in microbial biomass production (Eisenhauer et al., 2011).

2) Fauna eat microbes and may alter their populations: direct feeding - such as bacteria-feeding protozoa and nematodes and fungi-feeding arthropods and enchytraeids worms - can alter microbial population size and activity, which would likely have diverse effects on the functioning of the soil MCP. First, consumption of microbial biomass could enhance the rate of microbial turnover and potentially reduce the standing stock of active biomass. Alternatively, microbial populations may be stimulated by and show over-compensatory growth in the presence of microbivores due to the removal of hyphae and the release of nutrients from the feces and other waste produced by the grazers (Hanlon, 1981; Fu et al., 


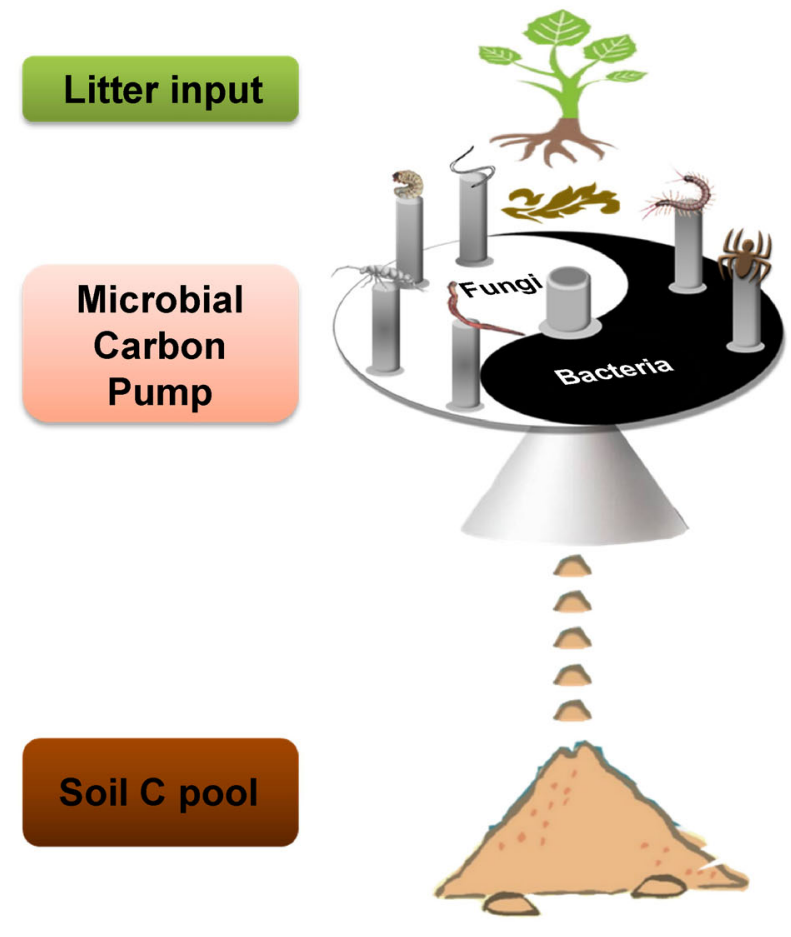

A

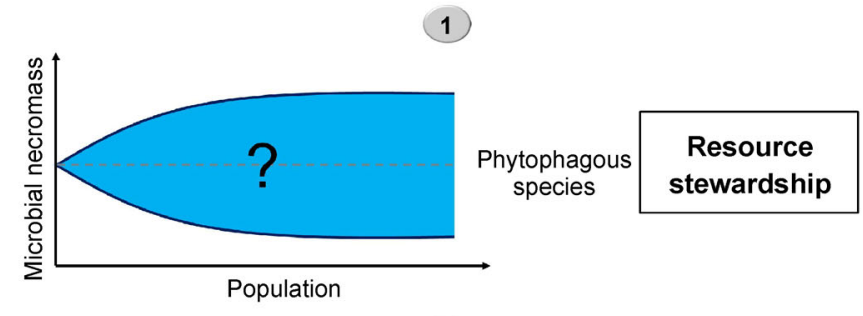

(2)

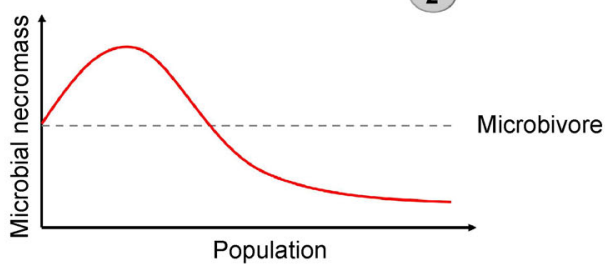

Population stewardship
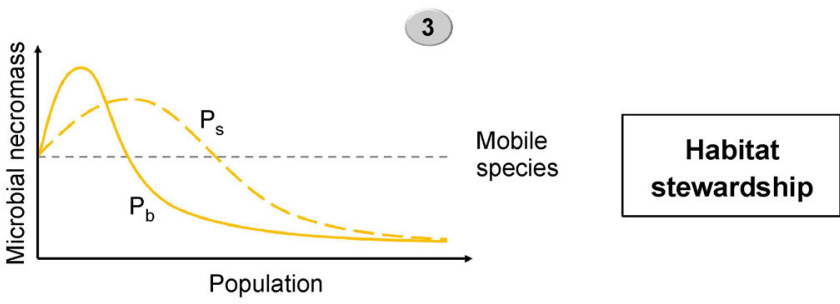

B

Fig. 2 Soil fauna manipulate MCP with effects dependent on functional guilds. The left part $(A)$ is a stylized illustration of soil fauna as a "butler" of the soil MCP. The right part (B) illustrates hypothesized microbial necromass dynamics for different functional guilds of soil fauna, which regulate the soil MCP through their effects on carbon resources (herbivore and detritivore), microbial populations (microbivore), and soil habitat (all mobile organisms). The dotted lines indicate the size of the microbial necromass pool before introducing soil fauna. The letter "P" (size + mobility) is used to index the capability of soil fauna to remold a soil's structure (here $P_{b}>P_{s}$ ).

2005; Crowther et al., 2012). Further yet, microbes may also respond to faunal grazing by shifting resource allocation from growth to defense via the production of secondary metabolites (Fine et al., 2006; Böllmann et al., 2010). Under all of these potential scenarios, faunal grazing may substantially change microbial growth efficiency and subsequent contributions of microbial-derived $\mathrm{C}$ to SOM.

3) Burrowing animals may mix soils and disrupt soil structures: movement of fauna through soils could increase the accessibility of organic matter to microbes by increasing the rate of aggregate turnover, transporting microbes to patches with available substrates, or alter the distribution of $\mathrm{C}$ and $\mathrm{N}$ in soils (Li et al., 2002; Jouquet et al., 2006; Wilkinson et al., 2009), which may stimulate the soil MCP for producing higher microbial biomass. However, extensive soil disturbance caused by faunal activities might also reduce the $C$ stabilization by reducing occlusion and physical protection of organic matter (Wolters, 2000), part of which is the microbial necromass that can be degraded due to reducing entombing effect in this scenario.

These mentioned mechanisms conceptually partition soil faunal effects on the soil MCP into three simplified mechanistic categories (modification of plant-derived resources for microbial communities, direct modification of microbial community size and composition, and alteration of SOM accessibility); those mechanisms, however, rarely exist in isolation. For example, most phytophagous insects and microbivores in soils are likely to move within the soil matrix in search of better food, water and air resources. Some animals, such as earthworms - which are well known as active movers within soils - can feed on both plant detritus and microorganisms (Lavelle, 1997). While there exist many challenges to disentangle the exact faunal controls on soil microbial processes, their interactions, and feedbacks among different faunal guilds, the existence of enormous knowledge gaps to integrate soil fauna and microbial necromass offers great opportunities for improved understanding and progress in explaining how soil animals manipulate the soil MCP and contribute to SOM formation.

\section{Appraisal on the soil MCP}

\subsection{Biomarker approach to study microbial necromass}

The soil MCP can be evaluated by quantifying absolute 
abundance of microbial necromass in soil and relative abundance of its proportion in SOC. Direct measurement of microbial necromass is difficult since it is hard to differentiate the $\mathrm{C}$ in microbial residues from non-microbial organic $\mathrm{C}$. Microbial residues comprise a complex mixture of compounds; there are, however, characteristic biomarkers that can be used to trace the microbial origin of SOC. Those biomarkers do not indicate living microbial biomass, but rather, microbial necromass. Theoretically, any organic compounds contained in microbial cells that are preserved in soils over long periods may help identify the mechanisms of SOM transformation and microbial necromass dynamics. However, a particularly useful microbial biomarkers are amino sugars; they are absent in plants (Amelung, 2001), stable against fluctuations in microbial activities (Nannipieri et al., 1979; Chantigny et al., 1997), and can be stabilized after cell death (Glaser et al., 2004). Additionally, different microbial groups produce different amino sugars; fungi produce the majority of glucosamine while bacteria produce muramic acid (Amelung, 2001). To convert biomarker mass to necromass, conversion factors of 9 and 45 have been suggested for converting glucosamine and muramic acid to fungal and bacterial necromass-C, respectively (Appuhn and Joergensen, 2006). Analysis of amino sugar concentration, composition and dynamics over time can link microorganisms at the gross community level to SOC sequestration under different environmental conditions (Guggenberger et al., 1999; Amelung, 2001; Glaser et al., 2004; Joergensen and Emmerling, 2006; Niggemann and Schubert, 2006; Ding et al., 2015; Liang et al., 2015; Joergensen, 2018).

Coupling amino sugar biomarkers with stable isotope analysis adds an additional level of analytical power to 1) quantify sequestration and turnover of specific organic compounds in the environment (Glaser, 2005), and 2) trace the origin of organic substances (Boschker and Middelburg, 2002). Isotopic analysis of amino sugars can offer unique opportunities to link the microbial groups (fungi or bacteria) involved with the necromass storage (total amino sugar content) and the necromass accumulation rate (isotope ${ }^{13} \mathrm{C}$ assimilation) (Glaser and Gross, 2005; Liang and Balser, 2010). In such applications, the isotopic changes in amino sugar compounds allow us to directly differentiate and quantitatively assess newly biosynthesized vs. old extant amino sugars (Glaser and Gross, 2005; He et al., 2006). To date, various methods have been developed to measure the ${ }^{13} \mathrm{C}$ in amino sugars including: gas chromatography/combustion/isotope ratio mass spectrometry (GC/c/lRMS) (Glaser and Gross, 2005; Decock et al., 2009), liquid chromatography/ isotope ratio mass spectrometry (LC/IRMS) (Bodé et al., 2009; Bai et al., 2013), gas chromatography/mass spectrometry (GC/MS) (He et al., 2005), and ion chromatography/ oxidation/isotope ratio mass spectrometry (IC/o/IRMS) (Dippold et al., 2014). All methods were developed to trace $C$ flows through microbial biomass to microbial-derived $C$ accumulation in soils. IRMS measures isotope $\mathrm{C}$ by analyzing the $\delta^{13} \mathrm{C}$ of individual amino sugar compounds at close to natural abundance, in which the LC/IRMS and IC/o/IRMS methods do not demand the derivatization step that can produce large analytical errors due to high variability in correcting $\delta^{13} \mathrm{C}$ values caused by error propagation (Decock et al., 2009); GC/ MS is a suitable solution in experiments with highly artificial concentrations of ${ }^{13} \mathrm{C}$ (e.g., incubation with a highly ${ }^{13} \mathrm{C}$ labeled substrate), providing structural information about how the substrate-C is incorporated into newly-synthesized amino sugars during microbial transformation (He et al., 2005; Liang and Balser, 2010). Except for IC/o/IRMS, all other mentioned approaches have been successfully used to assess microbial $C$ transformation and necromass accumulation over time in soils under natural abundance (e.g., C3 to C4 plant conversion) or artificial ${ }^{13} \mathrm{C}$-labeled conditions (Glaser, 2005).

\subsection{Caveats and limitations}

In soil studies with an aim on $C$ sequestration, it is necessary to account for the features of persistent $C$ and investigate the mechanisms protecting that $\mathrm{C}$ from decomposition. Such insights into the stabilization of SOM are essential because it is the slow turnover SOM pool that determines $C$ sequestration in soil. Characterizing and quantifying this pool and its underlying protection mechanisms are not straightforward and have eluded researchers for decades. To this end, we focus on microbial necromass, since mounting evidence indicates that this microbial necromass plays an important role in soil $\mathrm{C}$ storage. Importantly, microbial necromass has the unique ability to provide information that integrates beyond a brief snapshot of direct observations, which is crucial for acquiring a long-term perspective on the SOM dynamics. Unfortunately, suitable approaches for investigating microbial necromass are limited; to date, the amino sugar biomarker analysis is the most often used, while other approaches have been used only sporadically. Despite that the fact that we need an array of necromass analysis approaches which go beyond just amino sugars for cross validation, there also remain challenges with using amino sugars.

First, SOM is a heterogeneous mixture of compounds from a number of sources, and the presence of non-amino sugar compounds may interfere with soil amino sugar determination. Following the widely-used aldononitrile acetate derivatization GC-FID protocol (Guerrant and Moss, 1984; Zhang and Amelung, 1996; Liang et al., 2012), Liang et al. (2009a; $2009 b)$ detected significant interference by aminoglycoside antibiotics, compromising the utility of glucosamine and muramic acid as reliable microbial necromass biomarkers under certain conditions. Such issues serve as a cautionary note regarding the potential limitations when biomarkers identified in pure laboratory cultures are applied to natural environments. Second, the mixture of compounds that comprise SOM exists in a successive stage of degradation, and the decomposition stage of polymers consisting of amino sugar monomers can affect the efficiency of amino sugar extraction. The amino sugars that are extracted from soils exist in situ as structural components of polymers, such as 
peptidoglycan, which need to be broken down by hydrolysis to release amino sugar monomers for determination (Amelung, 2001). The amino sugar binding polymers of varying decomposition degrees differ in chemical structure and thus reactivity, leading to different efficiency of hydrolysis release of amino sugar monomers and their ultimate quantifications. Indeed, whether the extracted biomarker compounds are from young or older $C$ pools could lead to inconsistent interpretation when evaluating $\mathrm{C}$ stabilization based on the biomarker compounds. For example, newly-synthesized amino acids were found to decompose faster than originally-present counterparts (Zhang et al., 2015). Such difference in stability among "old and new" amino acids engenders concern and the need to investigate whether this distinct $C$ stabilization of identifiable and identical organic molecules extracted from soils occurs with amino sugars as well. Third, as organic matter is degraded in soils, it ubiquitously leads to a sequence of molecular changes in chemical structure, accompanying with numerous varied products with embedded monomer structures of interest (e.g., amino sugars). It is reasonable to expect that some amino sugar-containing polymers have undergone only slight changes (but that change happened to amino sugar chemical skeleton) during microbial attack and thus might escape the "analytical window" of the amino sugar analysis. In another words, slight changes in the structural composition of a compound during biodegradation may sufficiently alter the structure so that its intrinsic target component is no longer recognizable at the molecular level, while intensive changes may not be necessary to destroy the target moiety of polymers to influence biomarker determination. Fourth, bias exists for the interpretations on microbial necromass stability in soil based on the mere use of amino sugar compounds combined with stable $C$ isotope technique. Uncertainties of residence time will happen to molecular compounds and its inside " $\mathrm{C}$," when using isotopic $\mathrm{C}$ signature to calculate the residence time of parent molecular compounds (i.e., amino sugars), which overestimates molecule's stability. In simple words, while the $C$ from amino sugar compounds might logically persist in soils for a longer while, during that time the structure of the amino sugar molecule is likely to change as the initial compound is broken down and the $C$ is reused in new components; in that instance, the longer mean residence time of the inside " $C$ " simply indicates that microbes repeatedly cycle the isotope $C$ through their own biomass, rather than long residence time of those $C$ in the compound.

\section{Closing remarks}

Studies on microbial necromass stabilization in soils are imperative to understand soil $\mathrm{C}$ stabilization, advance current $\mathrm{C}$ cycling models, and help craft climate policy. The soil MCP conceptualizes a sequestration mechanism leading to the new formed SOC via accumulating microbial anabolisminduced organic compounds belowground. I overviewed our knowledge on the mechanism and appraisal of soil MCP, and discussed how microbial necromass gets shaped in soils and how it gets evaluated. Our awareness on the mechanism and our capability on measuring microbial necromass are far to be fully satisfactory, consequently leading to much uncertainty to project $C$ dynamics under global change and limited ability to manage soil MCP for $\mathrm{C}$ sequestration that facilitates ecosystem services of concern. I am eager to call new investigations to obtain empirical data in soil microbial necromass research area, which urgently awaits enriched studies and model development to relate to $\mathrm{C}$ cycle and climate change.

\section{Acknowledgments}

I would like to thank Drs. X. Zhang, T. Balser, J. Tiedje, J. Jastrow, E. DeLucia and M. Kästner for their supports along with the idea evolution and career development of C. Liang. I would like to thank Drs. H. Gan and K. Wickings for discussions on soil fauna, Dr. M. Zhu for discussions biomarker chemistry, Drs. J. Schimel and J. Lehmann for offering general insightful comments, and Dr. $X$. Zhu for improving visual quality of the figures. This work was supported by the National Natural Science Foundation of China (No. 31930070, 41977051). The grants or other support to C. Liang from the K. C. Wong Education Foundation of China (No. GJTD-2019-10) and the Alexander von Humboldt Foundation of Germany are also acknowledged with gratitude.

\section{Competing financial interests}

The author declares no competing financial interests.

\section{References}

Amelung, W., 2001. Methods using amino sugars as markers for microbial residues in soil, In: Lal, R., Kimble, J.M., Follett, R.F., Stewart B.A., eds. Assessment Methods for Soil Carbon. CRC/ Lewis Publishers, Boca Raton, FL, pp. 233-270.

Amelung, W., Kimble, J.M., Samson-Liebig, S., Follett, R.F., 2001. Restoration of microbial residues in soils of the conservation reserve program. Soil Science Society of America Journal 65, 1704-1709.

Anderson, T.H., Joergensen, R.G., 1997. Relationship between SIR and FE estimates of microbial biomass $C$ in deciduous forest soils at different $\mathrm{pH}$. Soil Biology \& Biochemistry 29, 1033-1042.

Anthony, M.A., Crowther, T.W., Maynard, D.S., van den Hoogen, J., Averill, C., 2020. Distinct assembly processes and microbial communities constrain soil organic carbon formation. One Earth 2, 349-360.

Appuhn, A., Joergensen, R., 2006. Microbial colonisation of roots as a function of plant species. Soil Biology \& Biochemistry 38, 1040 1051.

Bai, Z., Bodé, S., Huygens, D., Zhang, X., Boeckx, P., 2013. Kinetics of amino sugar formation from organic residues of different quality. Soil Biology \& Biochemistry 57, 814-821.

Baldock, J.A., Skjemstad, J.O., 2000. Role of the soil matrix and 
minerals in protecting natural organic materials against biological attack. Organic Geochemistry 31, 697-710.

Bardgett, R.D., van der Putten, W.H., 2014. Belowground biodiversity and ecosystem functioning. Nature 515, 505-511.

Bodé, S., Denef, K., Boeckx, P., 2009. Development and evaluation of a high-performance liquid chromatography/isotope ratio mass spectrometry methodology for $\delta^{13} \mathrm{C}$ analyses of amino sugars in soil. Rapid Communications in Mass Spectrometry 23, 2519 2526.

Böllmann, J., Elmer, M., Wöllecke, J., Raidl, S., Hüttl, R.F., 2010. Defensive strategies of soil fungi to prevent grazing by Folsomia candida (Collembola). Pedobiologia 53, 107-114.

Boschker, H.T.S., Middelburg, J.J., 2002. Stable isotopes and biomarkers in microbial ecology. FEMS Microbiology Ecology 40, 85-95.

Bradford, M.A., Wieder, W.R., Bonan, G.B., Fierer, N., Raymond, P.A., Crowther, T.W., 2016. Managing uncertainty in soil carbon feedbacks to climate change. Nature Climate Change 6, 751-758.

Chantigny, M.H., Angers, D.A., Prevost, D., Vezina, L.P., Chalifour, F. P., 1997. Soil aggregation and fungal and cacterial biomass under annual and perennial cropping systems. Soil Science Society of America Journal 61, 262-267.

Cotrufo, M.F., Wallenstein, M.D., Boot, C.M., Denef, K., Paul, E., 2013. The Microbial Efficiency-Matrix Stabilization (MEMS) framework integrates plant litter decomposition with soil organic matter stabilization: do labile plant inputs form stable soil organic matter? Global Change Biology 19, 988-995.

Craig, M.E., Turner, B.L., Liang, C., Clay, K., Johnson, D.J., Phillips, R. P., 2018. Tree mycorrhizal type predicts within-site variability in the storage and distribution of soil organic matter. Global Change Biology 24, 3317-3330.

Creamer, C.A., Foster, A.L., Lawrence, C., McFarland, J., Schulz, M., Waldrop, M.P., 2019. Mineralogy dictates the initial mechanism of microbial necromass association. Geochimica et Cosmochimica Acta 260, 161-176.

Crowther, T.W., Boddy, L., Hefin Jones, T., 2012. Functional and ecological consequences of saprotrophic fungus-grazer interactions. ISME Journal 6, 1992-2001.

Crowther, T.W., Thomas, S.M., Maynard, D.S., Baldrian, P., Covey, K., Frey, S.D., van Diepen, L.T., Bradford, M.A., 2015. Biotic interactions mediate soil microbial feedbacks to climate change. Proceedings of the National Academy of Sciences of the United States of America 112, 7033-7038.

Dalal, R.C., 1998. Soil microbial biomass: What do the numbers really mean? Australian Journal of Experimental Agriculture 38, 649 665.

Decock, C., Denef, K., Bod, S., Six, J., Boeckx, P., 2009. Critical assessment of the applicability of gas chromatography-combustion-isotope ratio mass spectrometry to determine amino sugar dynamics in soil. Rapid Communications in Mass Spectrometry 23, 1201-1211.

Ding, X., Chen, S., Zhang, B., Liang, C., He, H., Horwath, W.R., 2019. Warming increases microbial residue contribution to soil organic carbon in an alpine meadow. Soil Biology \& Biochemistry 135, 13 19.

Ding, X., Han, X., Zhang, X., Qiao, Y., 2013. Effects of contrasting agricultural management on microbial residues in a Mollisol in China. Soil \& Tillage Research 130, 13-17.

Ding, X., Liang, C., Zhang, B., Yuan, Y., Han, X., 2015. Higher rates of manure application lead to greater accumulation of both fungal and bacterial residues in macroaggregates of a clay soil. Soil Biology \& Biochemistry 84, 137-146.

Ding, X., Zhang, B., Lü, X., Wang, J., Horwath, W.R., 2017. Parent material and conifer biome influence microbial residue accumulation in forest soils. Soil Biology \& Biochemistry 107, 1-9.

Dippold, M.A., Boesel, S., Gunina, A., Kuzyakov, Y., Glaser, B., 2014. Improved $\delta^{13} \mathrm{C}$ analysis of amino sugars in soil by ion chromatography-oxidation-isotope ratio mass spectrometry. Rapid Communications in Mass Spectrometry 28, 569-576.

Dungait, J.A.J., Hopkins, D.W., Gregory, A.S., Whitmore, A.P., 2012. Soil organic matter turnover is governed by accessibility not recalcitrance. Global Change Biology 18, 1781-1796.

Eisenhauer, N., Schlaghamerský, J., Reich, P.B., Frelich, L.E., 2011. The wave towards a new steady state: Effects of earthworm invasion on soil microbial functions. Biological Invasions 13, 2191 2196.

Eswaran, H., Van Den Berg, E., Reich, P., 1993. Organic carbon in soils of the world. Soil Science Society of America Journal 57, 192-194.

Fan, Z., Liang, C., 2015. Significance of microbial asynchronous anabolism to soil carbon dynamics driven by litter inputs. Scientific Reports 5, 9575.

Fine, P.V.A., Miller, Z.J., Italo, M., Sebastian, I., Appel, H.M., Stevens, M.H.H., Ilari, S.K.R., Schultz, J.C., Coley, P.D., 2006. The growthdefense trade-off and habitat specialization by plants in Amazonian forests. Ecology 87, 150-162.

Foley, J.A., DeFries, R., Asner, G.P., Barford, C., Bonan, G., Carpenter, S.R., Chapin, F.S., Coe, M.T., Daily, G.C., Gibbs, H. K., Helkowski, J.H., Holloway, T., Howard, E.A., Kucharik, C.J., Monfreda, C., Patz, J.A., Prentice, I.C., Ramankutty, N., Snyder, P. K., 2005. Global consequences of land use. Science 309, 570 574.

Frey, S.D., Drijber, R., Smith, H., Melillo, J., 2008. Microbial biomass, functional capacity, and community structure after 12 years of soil warming. Soil Biology \& Biochemistry 40, 2904-2907.

Fu, S., Ferris, H., Plant, R., Brown, D., 2005. Does the positive feedback effect of nematodes on the biomass and activity of their bacteria prey vary with nematode species and population size? Soil Biology \& Biochemistry 37, 1979-1987.

Gan, H., Liang, C., Wickings, K., 2018. Root herbivores accelerate carbon inputs to soil and drive changes in biogeochemical processes. Rhizosphere 6, 112-115.

Geyer, K.M., Kyker-Snowman, E., Grandy, A.S., Frey, S.D., 2016. Microbial carbon use efficiency: accounting for population, community, and ecosystem-scale controls over the fate of metabolized organic matter. Biogeochemistry 127, 173-188.

Glaser, B., 2005. Compound-specific stable-isotope $\left(\delta^{13} \mathrm{C}\right)$ analysis in soil science. Journal of Plant Nutrition and Soil Science 168, 633648.

Glaser, B., Gross, S., 2005. Compound-specific $\delta^{13} \mathrm{C}$ analysis of individual amino sugars - a tool to quantify timing and amount of soil microbial residue stabilization. Rapid Communications in Mass 
Spectrometry 19, 1409-1416.

Glaser, B., Millar, N., Blum, H., 2006. Sequestration and turnover of bacterial- and fungal-derived carbon in a temperate grassland soil under long-term elevated atmospheric $p \mathrm{CO}_{2}$. Global Change Biology 12, 1521-1531.

Glaser, B., Turrion, M.B., Alef, K., 2004. Amino sugars and muramic acid - biomarkers for soil microbial community structure analysis. Soil Biology \& Biochemistry 36, 399-407.

Grandy, A.S., Wieder, W.R., Wickings, K., Kyker-Snowman, E., 2016. Beyond microbes: Are fauna the next frontier in soil biogeochemical models? Soil Biology \& Biochemistry 102, 40-44.

Guerrant, G.O., Moss, C.W., 1984. Determination of monosaccharides as aldononitrile, O-methyloxime, alditol, and cyclitol acetate derivatives by gas chromatography. Analytical Chemistry 56, 633 638.

Guggenberger, G., Christensen, B.T., Zech, W., 1994. Land-use effects on the composition of organic matter in particle-size separates of soil: I. Lignin and carbohydrate signature. European Journal of Soil Science 45, 449-458.

Guggenberger, G., Frey, S.D., Six, J., Paustian, K., Elliott, E.T., 1999. Bacterial and fungal cell-wall residues in conventional and notillage agroecosystems. Soil Science Society of America Journal 63, 1188-1198.

Hanlon, R.D.G., 1981. Influence of grazing by collembola on the activity of senescent fungal colonies grown on media of different nutrient concentration. Oikos 36, 362-367.

$\mathrm{He}, \mathrm{H}$., Xie, H., Zhang, X., 2006. A novel GC/MS technique to assess ${ }^{15} \mathrm{~N}$ and ${ }^{13} \mathrm{C}$ incorporation into soil amino sugars. Soil Biology \& Biochemistry 38, 1083-1091.

He, H., Xie, H., Zhang, X., Wang, Y., Wu, Y., 2005. A gas chromatographic/mass spectrometric method for tracing the microbial conversion of glucose into amino sugars in soil. Rapid Communications in Mass Spectrometry 19, 1993-1998.

Hunter, M.D., 2001. Insect population dynamics meets ecosystem ecology: Effects of herbivory on soil nutrient dynamics. Agricultural \& Forest Entomology 3, 77-84.

Jastrow, J.D., Amonette, J.E., Bailey, V.L., 2007. Mechanisms controlling soil carbon turnover and their potential application for enhancing carbon sequestration. Climatic Change 80, 5-23.

Jastrow, J.D., Miller, R.M., Matamala, R., Norby, R.J., Boutton, T.W., Rice, C.W., Owensby, C.E., 2005. Elevated atmospheric carbon dioxide increases soil carbon. Global Change Biology 11, 20572064.

Jia, J., Feng, X., He, J.S., He, H., Lin, L., Liu, Z., 2017. Comparing microbial carbon sequestration and priming in the subsoil versus topsoil of a Qinghai-Tibetan alpine grassland. Soil Biology \& Biochemistry 104, 141-151.

Jiao, N., Herndl, G.J., Hansell, D.A., Benner, R., Kattner, G., Wilhelm, S.W., Kirchman, D.L., Weinbauer, M.G., Luo, T., Chen, F., Azam, F., 2010. Microbial production of recalcitrant dissolved organic matter: Long-term carbon storage in the global ocean. Nature Reviews. Microbiology 8, 593-599.

Jiao, N., Wang, H., Xu, G., Aricò, S., 2018. Blue carbon on the rise: Challenges and opportunities. National Science Review 5, 464 468.

Joergensen, R.G., 2018. Amino sugars as specific indices for fungal and bacterial residues in soil. Biology and Fertility of Soils 54, 559 568.

Joergensen, R.G., Emmerling, C., 2006. Methods for evaluating human impact on soil microorganisms based on their activity, biomass, and diversity in agricultural soils. Journal of Plant Nutrition and Soil Science 169, 295-309.

Joergensen, R.G., Mäder, P., Fließbach, A., 2010. Long-term effects of organic farming on fungal and bacterial residues in relation to microbial energy metabolism. Biology and Fertility of Soils 46, 303-307.

Jouquet, P., Dauber, J., Lagerlöf, J., Lavelle, P., Lepage, M., 2006. Soil invertebrates as ecosystem engineers: Intended and accidental effects on soil and feedback loops. Applied Soil Ecology 32, 153164.

Kallenbach, C.M., Frey, S.D., Grandy, A.S., 2016. Direct evidence for microbial-derived soil organic matter formation and its ecophysiological controls. Nature Communications 7, 13630.

Kallenbach, C.M., Grandy, A.S., Frey, S.D., Diefendorf, A.F., 2015. Microbial physiology and necromass regulate agricultural soil carbon accumulation. Soil Biology \& Biochemistry 91, 279-290.

Khan, K.S., Mack, R., Castillo, X., Kaiser, M., Joergensen, R.G., 2016. Microbial biomass, fungal and bacterial residues, and their relationships to the soil organic matter $\mathrm{C} / \mathrm{N} / \mathrm{P} / \mathrm{S}$ ratios. Geoderma 271, 115-123.

Kiem, R., Kogel-Knabner, I., 2003. Contribution of lignin and polysaccharides to the refractory carbon pool in C-depleted arable soils. Soil Biology \& Biochemistry 35, 101-118.

Kivlin, S.N., Waring, B.G., Averill, C., Hawkes, C.V., 2013. Tradeoffs in microbial carbon allocation may mediate soil carbon storage in future climates. Frontiers in Microbiology 4, 4.

Knicker, H., 2000. Nature of organic nitrogen in fine particle size separates of sandy soils of highly industrialized areas as revealed by NMR spectroscopy. Soil Biology \& Biochemistry 32, 241-252.

Knicker, H., 2004. Stabilization of $\mathrm{N}$-compounds in soil and organicmatter-rich sediments- what is the difference? Marine Chemistry 92, 167-195.

Kögel-Knabner, I., 2002. The macromolecular organic composition of plant and microbial residues as inputs to soil organic matter. Soil Biology \& Biochemistry 34, 139-162.

Kögel-Knabner, I., Guggenberger, G., Kleber, M., Kandeler, E., Kalbitz, K., Scheu, S., Eusterhues, K., Leinweber, P., 2008. Organo-mineral associations in temperate soils: Integrating biology, mineralogy, and organic matter chemistry. Journal of Plant Nutrition and Soil Science 171, 61-82.

Kubicki, J.D., Schroeter, L.M., Itoh, M.J., Nguyen, B.N., Apitz, S.E., 1999. Attenuated total reflectance Fourier-transform infrared spectroscopy of carboxylic acids adsorbed onto mineral surfaces. Geochimica et Cosmochimica Acta 63, 2709-2725.

Lauer, F., Kösters, R., Preez, C.C.D., Amelung, W., 2011. Microbial residues as indicators of soil restoration in South African secondary pastures. Soil Biology \& Biochemistry 43, 787-794.

Lavelle, P., 1997. Faunal Activities and Soil Processes: Adaptive Strategies That Determine Ecosystem Function, In: Fitter, M.B.a.A. $\mathrm{H}$., ed. Advances in Ecological Research. Academic Press, pp. 93-132.

Lechtenfeld, O.J., Hertkorn, N., Shen, Y., Witt, M., Benner, R., 2015. 
Marine sequestration of carbon in bacterial metabolites. Nature Communications 6, 6711.

Lee, Z.M., Schmidt, T.M., 2014. Bacterial growth efficiency varies in soils under different land management practices. Soil Biology \& Biochemistry 69, 282-290.

Lehmann, J., Kinyangi, J., Solomon, D., 2007. Organic matter stabilization in soil microaggregates: implications from spatial heterogeneity of organic carbon contents and carbon forms. Biogeochemistry 85, 45-57.

Lehmann, J., Kleber, M., 2015. The contentious nature of soil organic matter. Nature 528, 60-68.

Li, X., Fisk, M.C., Fahey, T.J., Bohlen, P.J., 2002. Influence of earthworm invasion on soil microbial biomass and activity in a northern hardwood forest. Soil Biology \& Biochemistry 34, 19291937.

Liang, C., Amelung, W., Lehmann, J., Kästner, M., 2019. Quantitative assessment of microbial necromass contribution to soil organic matter. Global Change Biology 25, 3578-3590.

Liang, C., Balser, T.C., 2008. Preferential sequestration of microbial carbon in subsoils of a glacial-landscape toposequence, Dane County, WI, USA. Geoderma 148, 113-119.

Liang, C., Balser, T.C., 2010. Mass spectrometric characterization of amino sugar aldononitrile acetate derivatives used for isotope enrichment assessment of microbial residues. Soil Biology \& Biochemistry 42, 904-909.

Liang, C., Balser, T.C., 2011. Microbial production of recalcitrant organic matter in global soils: Implications for productivity and climate policy. Nature Reviews. Microbiology 9, 75.

Liang, C., Balser, T.C., 2012. Warming and nitrogen deposition lessen microbial residue contribution to soil carbon pool. Nature Communications 3, 1222.

Liang, C., Cheng, G., Wixon, D., Balser, T., 2011. An Absorbing Markov Chain approach to understanding the microbial role in soil carbon stabilization. Biogeochemistry 106, 303-309.

Liang, C., Duncan, D.S., Balser, T.C., Tiedje, J.M., Jackson, R.D., 2013. Soil microbial residue storage linked to soil legacy under biofuel cropping systems in southern Wisconsin, USA. Soil Biology \& Biochemistry 57, 939-942.

Liang, C., Gutknecht, J.L.M., Balser, T.C., 2015. Microbial lipid and amino sugar responses to long-term simulated global environmental changes in a California annual grassland. Frontiers in Microbiology 6, 385.

Liang, C., Pedersen, J.A., Balser, T.C., 2009a. Aminoglycoside antibiotics may interfere with microbial amino sugar analysis. Journal of Chromatography. A 1216, 5296-5301.

Liang, C., Read, H., Balser, T., 2009b. Reliability of muramic acid as a bacterial biomarker is influenced by methodological artifacts from streptomycin. Microbial Ecology 57, 494-500.

Liang, C., Read, H.W., Balser, T.C., 2012. GC-based detection of aldonitrile acetate derivatized glucosamine and muramic acid for microbial residue determination in soil samples: analytical protocol and derivative validation. Journal of Visualization Experiment 63, 3767.

Liang, C., Schimel, J.P., Jastrow, J.D., 2017. The importance of anabolism in microbial control over soil carbon storage. Nature Microbiology 2, 17105.
Liang, C., Zhang, X., Balser, T.C., 2007. Net microbial amino sugar accumulation process in soil as influenced by different plant material inputs. Biology and Fertility of Soils 44, 1-7.

Ludwig, M., Achtenhagen, J., Miltner, A., Eckhardt, K.U., Leinweber, P., Emmerling, C., Thiele-Bruhn, S., 2015. Microbial contribution to SOM quantity and quality in density fractions of temperate arable soils. Soil Biology \& Biochemistry 81, 311-322.

Ma, T., Zhu, S., Wang, Z., Chen, D., Dai, G., Feng, B., Su, X., Hu, H., Li, K., Han, W., Liang, C., Bai, Y., Feng, X., 2018. Divergent accumulation of microbial necromass and plant lignin components in grassland soils. Nature Communications 9, 3480.

Malik, A.A., Martiny, J.B.H., Brodie, E.L., Martiny, A.C., Treseder, K.K., Allison, S.D., 2020. Defining trait-based microbial strategies with consequences for soil carbon cycling under climate change. ISME Journal 14, 1-9.

Malik, A.A., Roth, V.N., Hébert, M., Tremblay, L., Dittmar, T., Gleixner, G., 2016. Linking molecular size, composition and carbon turnover of extractable soil microbial compounds. Soil Biology \& Biochemistry 100, 66-73.

Martins, M.R., Angers, D.A., Corá, J.E., 2012. Co-accumulation of microbial residues and particulate organic matter in the surface layer of a no-till Oxisol under different crops. Soil Biology \& Biochemistry 50, 208-213.

McCarthy, J.F., llavsky, J., Jastrow, J.D., Mayer, L.M., Perfect, E., Zhuang, J., 2008. Protection of organic carbon in soil microaggregates via restructuring of aggregate porosity and filling of pores with accumulating organic matter. Geochimica et Cosmochimica Acta 72, 4725-4744.

Mikutta, R., Kleber, M., Torn, M., Jahn, R., 2006. Stabilization of soil organic matter: association with minerals or chemical recalcitrance? Biogeochemistry 77, 25-56.

Miltner, A., Bombach, P., Schmidt-Brücken, B., Kästner, M., 2012. SOM genesis: Microbial biomass as a significant source. Biogeochemistry 111, 41-55.

Monreal, C.M., Sultan, Y., Schnitzer, M., 2010. Soil organic matter in nano-scale structures of a cultivated Black Chernozem. Geoderma 159, 237-242.

Mooney, H.A., Canadell, J., Chapin, F.S. III, Ehleringer, J.H., Korner, C., McMurtrie, R.E., Parton, W.J., Pitelka, L.F., Schulze, E.D., 1999. Ecosystem physiology responses to global change, In: Walker, B., ed. The Terrestrial Biosphere and Global Change. Cambridge University Press, pp. 141-189.

Moritz, L.K., Liang, C., Wagai, R., Kitayama, K., Balser, T.C., 2009. Vertical distribution and pools of microbial residues in tropical forest soils formed from distinct parent materials. Biogeochemistry 92, 83-94.

Morrissey, E.M., Mchugh, T.A., Preteska, L., Hayer, M., Dijkstra, P., Hungate, B.A., Schwartz, E., 2015. Dynamics of extracellular DNA decomposition and bacterial community composition in soil. Soil Biology \& Biochemistry 86, 42-49.

Nannipieri, P., Pedrazzini, F., Arcara, P.G., Piovanelli, C., 1979. Changes in amino-acids, enzyme-activities, and biomasses during soil microbial-growth. Soil Science 127, 26-34.

Niggemann, J., Schubert, C.J., 2006. Sources and fate of amino sugars in coastal Peruvian sediments. Geochimica et Cosmochimica Acta 70, 2229-2237. 
Poeplau, C., Helfrich, M., Dechow, R., Szoboszlay, M., Tebbe, C.C. Don, A., Greiner, B., Zopf, D., Thumm, U., Korevaar, H., Geerts, R., 2019. Increased microbial anabolism contributes to soil carbon sequestration by mineral fertilization in temperate grasslands. Soil Biology \& Biochemistry 130, 167-176.

Potthoff, M., Dyckmans, J., Flessa, H., Beese, F., Joergensen, R. 2008. Decomposition of maize residues after manipulation of colonization and its contribution to the soil microbial biomass. Biology and Fertility of Soils 44, 891-895.

Pronk, G.J., Heister, K., Kögel-Knabner, I., 2015. Amino sugars reflect microbial residues as affected by clay mineral composition of artificial soils. Organic Geochemistry 83-84, 109-113.

Rillig, M.C., Wright, S.F., Nichols, K.A., Schmidt, W.F., Torn, M.S., 2001. Large contribution of arbuscular mycorrhizal fungi to soil carbon pools in tropical forest soils. Plant \& Soil 233, 167-177.

Roller, B.R.K., Stoddard, S.F., Schmidt, T.M., 2016. Exploiting rRNA operon copy number to investigate bacterial reproductive strategies. Nature Microbiology 1, 16160.

Rumpel, C., Eusterhues, K., Kögel-Knabner, I., 2010. Non-cellulosic neutral sugar contribution to mineral associated organic matter in top- and subsoil horizons of two acid forest soils. Soil Biology $\&$ Biochemistry 42, 379-382.

Schimel, J., Schaeffer, S.M., 2012. Microbial control over carbon cycling in soil. Frontiers in Microbiology 3, 1-11.

Schlautman, M.A., Morgan, J.J., 1994. Adsorption of aquatic humic substances on colloidal-size aluminum oxide particles: Influence of solution chemistry. Geochimica et Cosmochimica Acta 58, 4293 4303.

Schmidt, M.W.I., Torn, M.S., Abiven, S., Dittmar, T., Guggenberger, G., Janssens, I.A., Kleber, M., Kogel-Knabner, I., Lehmann, J., Manning, D.A.C., Nannipieri, P., Rasse, D.P., Weiner, S., Trumbore, S.E., 2011. Persistence of soil organic matter as an ecosystem property. Nature 478, 49-56.

Shao, P., Liang, C., Lynch, L., Xie, H., Bao, X., 2019. Reforestation accelerates soil organic carbon accumulation: Evidence from microbial biomarkers. Soil Biology \& Biochemistry 131, 182-190.

Simpson, A.J., Simpson, M.J., Smith, E., Kelleher, B.P., 2007. Microbially derived inputs to soil organic matter: Are current estimates too low? Environmental Science \& Technology 41, 8070-8076.

Sokol, N.W., Bradford, M.A., 2019. Microbial formation of stable soil carbon is more efficient from belowground than aboveground input. Nature Geoscience 12, 46-53.

Sokol, N.W., Sanderman, J., Bradford, M.A., 2019. Pathways of mineral-associated soil organic matter formation: Integrating the role of plant carbon source, chemistry, and point of entry. Global Change Biology 25, 12-24.

Sollins, P., Homann, P., Caldwell, B.A., 1996. Stabilization and destabilization of soil organic matter: Mechanisms and controls. Geoderma 74, 65-105.

Solomon, D., Lehmann, J., Zech, W., 2001. Land use effects on amino sugar signature of chromic Luvisol in the semi-arid part of northern Tanzania. Biology and Fertility of Soils $33,33-40$.

Soong, J.L., Vandegehuchte, M.L., Horton, A.J., Nielsen, U.N., Denef, K., Shaw, E.A., Tomasel, C.M.D., Parton, W., Wall, D.H., Cotrufo, M.F., 2016. Soil microarthropods support ecosystem productivity and soil $C$ accrual: Evidence from a litter decomposition study in the tallgrass prairie. Soil Biology \& Biochemistry 92, 230-238.

Stevenson, F., 1994. Humus Chemistry: Genesis, Composition, Reactions. 2nd ed. John Wiley \& Sons, New York.

Stockmann, U., Adams, M.A., Crawford, J.W., Field, D.J., Henakaarchchi, N., Jenkins, M., Minasny, B., McBratney, A.B., Courcelles, V.R., Singh, K., Wheeler, I., Abbott, L., Angers, D.A., Baldock, J., Bird, M., Brookes, P.C., Chenu, C., Jastrow, J.D., Lal, R., Lehmann, J., O'Donnell, A.G., Parton, W.J., Whitehead, D., Zimmermann, M., 2013. The knowns, known unknowns and unknowns of sequestration of soil organic carbon. Agriculture, Ecosystems \& Environment 164, 80-99.

Swift, R.G., 2001. Sequestration of carbon by soil. Soil Science 166, 858-871.

Tao, W., Zhaomo, T., Per, B., Anders, T., Per, P., 2017. Mineral surface-reactive metabolites secreted during fungal decomposition contribute to the formation of soil organic matter. Environmental Microbiology 19, 5117-5129.

van Groenigen, K.J., Six, J., Harris, D., Van Kessel, C., 2007. Elevated $\mathrm{CO}_{2}$ does not favor a fungal decomposition pathway. Soil Biology \& Biochemistry 39, 2168-2172.

van Groenigen, K.J., Six, J., Hungate, B.A., de Graaff, M.A., van Breemen, N., van Kessel, C., 2006. Element interactions limit soil carbon storage. Proceedings of the National Academy of Sciences of the United States of America 103, 6571-6574.

von Lützow, M., Kögel-Knabner, I., Ekschmitt, K., Matzner, E., Guggenberger, G., Marschner, B., Flessa, H., 2006. Stabilization of organic matter in temperate soils: Mechanisms and their relevance under different soil conditions-a review. European Journal of Soil Science 57, 426-445.

Wardle, D.A., 1992. A comparative assessment of factors which influence microbial biomass carbon and nitrogen levels in soil. Biological Reviews of the Cambridge Philosophical Society 67 , 321-358.

Whitman, W.B., Coleman, D.C., Wiebe, W.J., 1998. Prokaryotes: The unseen majority. Proceedings of the National Academy of Sciences of the United States of America 95, 6578-6583.

Wilkinson, M.T., Richards, P.J., Humphreys, G.S., 2009. Breaking ground: Pedological, geological, and ecological implications of soil bioturbation. Earth-Science Reviews 97, 257-272.

Wolters, V., 2000. Invertebrate control of soil organic matter stability. Biology and Fertility of Soils 31, 1-19.

Xu, X., Thornton, P.E., Post, W.M., 2013. A global analysis of soil microbial biomass carbon, nitrogen and phosphorus in terrestrial ecosystems. Global Ecology and Biogeography 22, 737-749.

Zhang, B., Drury, C.F., Yang, X., Reynolds, W.D., Zhang, X., 2014. Effects of long-term and recently imposed tillage on the concentration and composition of amino sugars in a clay loam soil in Ontario, Canada. Soil \& Tillage Research 135, 9-17.

Zhang, B., Liang, C., He, H., Zhang, X., 2013. Variations in soil microbial communities and residues along an altitude gradient on the Northern Slope of Changbai Mountain, China. PLoS One 8, e66184

Zhang, W., Liang, C., Kao-Kniffin, J., He, H., Xie, H., Zhang, H., Zhang, X., 2015. Differentiating the mineralization dynamics of the originally present and newly synthesized amino acids in soil 
amended with available carbon and nitrogen substrates. Soil Biology \& Biochemistry 85, 162-169.

Zhang, X., Amelung, W., 1996. Gas chromatographic determination of muramic acid, glucosamine, mannosamine, and galactosamine in soils. Soil Biology \& Biochemistry 28, 1201-1206.

Zhang, X., Amelung, W., Yuan, Y., Samson-Liebig, S., Brown, L., Zech, W., 1999. Land-use effects on amino sugars in particle size fractions of an Argiudoll. Applied Soil Ecology 11, 271-275.
Zhu, X., Liang, C., Masters, M.D., Kantola, I.B., DeLucia, E.H., 2018. The impacts of four potential bioenergy crops on soil carbon dynamics as shown by biomarker analyses and DRIFT spectroscopy. Global Change Biology. Bioenergy 10, 489-500.

Zhu, X., Xie, H., Masters, M.D., Luo, Y., Zhang, X., Liang, C., 2020. Microbial trade-off in soil organic carbon storage in a no-till continuous corn agroecosystem. European Journal of Soil Biology 96, 103146. 